\title{
Low molecular weight chemicals, hypersensitivity, and direct toxicity: the acid anhydrides
}

\author{
KATHERINE M VENABLES \\ From the Department of Occupational Medicine, National Heart and Lung Institute, Brompton Hospital, \\ London SW3 6HP, UK
}

ABSTRACT The acid anhydrides are a group of reactive chemicals used widely in alkyd and epoxy resins. The major hazards to health are mucosal and skin irritation and sensitisation of the respiratory tract. Most occupational asthma caused by acid anhydrides appears to be immunologically mediated. Immunological mechanisms have been proposed to explain an influenza-like syndrome and pulmonary haemorrhage, but direct toxicity may also be important in the aetiology of these conditions.

Acid anhydrides are reactive organic chemicals of low molecular weight which have been used in industry for over 50 years. Their major toxic effects are irritation of mucous membranes and hypersensitivity, in particular asthma (tables 1 and 2). ${ }^{1-74}$ These are not unusual effects and other reactive chemicals, such as isocyanates and amines, have a similar spectrum of toxicity. But the acid anhydrides are of special interest because in vitro tests for the immunological response to them have been developed in the past ten years which give a new dimension to clinical and epidemiological research.

\section{Industrial uses}

Acid anhydrides are named after their parent acid. Acetic anhydride is the simplest member of the family. Figure 1 shows the chemical structures of those reported to cause asthma: phthalic anhydride (PA), tetrachlorophthalic anhydride (TCPA), trimellitic anhydride (TMA), hexahydrophthalic anhydride (HHPA), himic anhydride (HA), maleic anhydride (MA), and pyromellitic dianhydride (PMDA).

The major uses of the chemicals are in alkyd and epoxy resins. ${ }^{75-79}$ PA is used to make phthalate plasticisers and other chemicals. Alkyd resins are named from alcohol and acid but anhydrides are often more reactive than their parent acids and are used instead. PA and MA are common constituents of alkyd resins, which form the base for paints, varnishes, and reinforced plastics. Epoxy resins are made from epichlorhydrin and bisphenol A (diphenoyl propane) and cured by a reactive chemical, such as an amine or acid anhydride. They have good adhesive strength, electrical insulation, and chemical resistance and are widely used in adhesives, casting, encapsulation, coating, sealants, printing inks, fabric treatment, and dental and surgical appliances, often in small work-

Table 1 Effects of acid anhydrides on man*

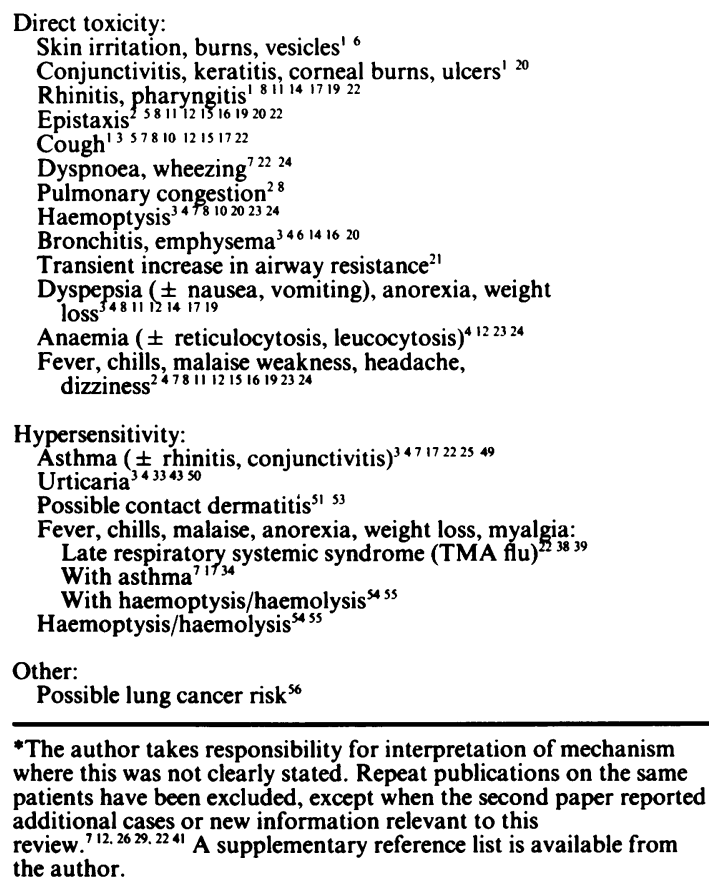


Table 2 Effects of acid anhydrides on animals

\begin{tabular}{ll}
\hline Inhalation & Mucosal irritation, other acute effects ${ }^{11535758}$ \\
& Pulmonary oedema, bleeding \\
Oral & Little toxicity 586061 \\
Eye & Eye irritation, corneal damage \\
Skin & Irritation, reddening, acantholysis ${ }^{586465}$ \\
Immunological & Sensitisation \\
\hline
\end{tabular}

places where occupational hygiene is poor.$^{80}$ Most acid anhydrides are solids and need heat for curing, which is expensive but, by contrast with amine hardeners, most of which are liquids and cure at room temperature in an exothermic reaction, allows for better control of the reaction, thus improving the mechanical and electrical properties of the cured resin. By the mid1960 s about ten acid anhydrides were of major commercial importance as epoxy hardeners.

\section{Direct toxicity}

Until the last ten years, most toxic effects reported were direct irritation of mucous membranes or skin; reports of hypersensitivity were rare (table 1). The balance has changed recently. Concerning other mechanisms of toxicity, one case-referent study has associated lung cancer with a factory which manufactured PA, ${ }^{56}$ but it also made acetylene and phthalates, and as it was not possible to group subjects by exposure to different chemicals, a specific association has not been shown.

Acid anhydrides can cause severe irritation, including skin burns, corneal ulcers, epistaxis, and haemoptysis (table 1). In animals they have caused eye damage, respiratory mucosal irritation, and pulmonary oedema and haemorrhage (table 2). The first report of occupational toxicity from acid anhydrides was made by the Chief Inspector of Factories and Workshops in his report for 1937.' Eight men developed mucosal irritation and a blistering rash after working with MA and three required sick leave for up to 40 days. In Japan $73 \%$ of 265 printers exposed to MA reported eye pain, lachrymation, and blurring of vision and 17 had signs of diffuse superficial keratitis. ${ }^{13}$ In toxicological studies of 180 chemicals Carpenter and Smyth scored damage to rabbit eyes on a 10 point scale and only two scored 10 , sodium hydroxide and MA.$^{62}$ Epistaxis is a prominent feature in early reports of PA toxicity and often continued after work to be noted on waking the next day. "12 Haemoptysis and "pulmonary congestion" due to PA were not uncommon in the 1940s and 1950s, reported first by Donnat in synthetic textile workers. ${ }^{7}$ TMA in powder epoxy coatings has caused haemoptysis in recent years. ${ }^{23} 245455$ The Health and Safety Executive's review of the toxicity of TMA included previously unpublished inhalation studies in animals ${ }^{58}$ which suggest that pulmonary oedema, haemorrhage, and acute inflammation increase in severity with increasing intensity of exposure.

These severe irritative effects appear related to heavy occupational exposure, such as occurred in the postwar organic chemical and plastics industries. Few early reports included environmental measurements, but occupational exposure to PA at $10-18 \mathrm{mg} / \mathrm{m}^{3}{ }^{14}$ and $4-40 \mathrm{mg} / \mathrm{m}^{3}{ }^{17}$ caused symptoms of mucosal irritation, the latter study reporting evidence for dose related symptoms. Indirect evidence suggesting heavy exposure comes from reports of environmental contamination in the 1950s and 1960 s. A German factory contaminated its environment with PA, affecting

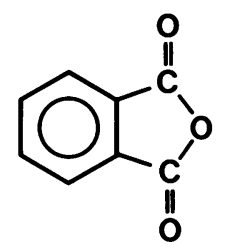

Phthalic anhydride<smiles>O=C(O)c1ccc2c(c1)C(=O)OC2=O</smiles>

Trimellitic anhydride<smiles>O=C1OC(=O)C2C3CCC(C3)C12</smiles>

Himic anhydride<smiles>O=C1OC(=O)c2c(Cl)c(Cl)c(Cl)c(Cl)c21</smiles>

Tetrachlorophthalic anhydride<smiles>O=C1OC(=O)C2CCCCC12</smiles>

Hexahydrophthalic anhydride<smiles>O=c1oc(=O)c2cc3c(=O)oc(=O)c3cc12</smiles>

Pyromellitic dianhydride<smiles>O=C1CCC(=O)O1</smiles>

Maleic anhydride

Fig 1 Acid anhydrides reported to cause asthma. 
vegetation, farm animals, and children in the local school. ${ }^{3}$ PA production plants in the United States caused eye irritation in local residents. ${ }^{81}$ Concentrations of MA around a Soviet factory were up to $3 \cdot 3$ $\mathrm{mg} / \mathrm{m}^{3}$ at $500 \mathrm{~m}$ distance and up to $2.6 \mathrm{mg} / \mathrm{m}^{3}$ at $1 \mathrm{~km} .{ }^{82}$ Irritative symptoms also occur in current working conditions: TMA at 1.7 to $4.7 \mathrm{mg} / \mathrm{m}^{3} 2241$ and 0.007 to $2.1 \mathrm{mg} / \mathrm{m}^{3} 38384$ has caused rhinitis, epistaxis, cough, dyspnoea, and wheezing. Most reports have expressed exposure as time weighted averages and the peak concentrations may have been much higher. This may explain why irritation still occurs today.

There is some evidence for individual variation in irritation. One report suggested blondes are more susceptible to skin burns basing this on observation of German prisoners conscripted to factory work in wartime France. ${ }^{2}$ In a study of acute effects of exposure to PA and tetrahydrophthalic anhydride on lung function workers with considerable past exposure had minor effects, but an investigator with asthma had a pronounced increase in airway resistance, requiring the use of a bronchodilator. ${ }^{21}$ There is a second report of an investigator with asthma experiencing an asthmatic attack on exposure to PA. ${ }^{34}$ Two reports have suggested that patients with pre-existing chronic bronchitis take longer to recover from accidental exposure to acid anhydride. ${ }^{620}$

Some reports of bronchitis or emphysema (table 1) are based on clinical observation rather than formal prospective studies and they may be erroneous. Two refer to spastic or asthmatic bronchitis ${ }^{1620}$ and the cases may have had asthma. The possibility that acid anhydrides cause chronic airway narrowing, however, cannot be discounted.

It is not clear if ingested acid anhydrides are toxic. Although animal experiments suggest they are not (table 2), acid anhydride containing dust impacted on the pharynx after inhalation may be swallowed and upper gastrointestinal irritation has been proposed ${ }^{512}$ as the mechanism for dyspeptic symptoms in exposed workers, which are sometimes accompanied by loss of weight or anaemia (table 1). Phthalic acid, the metabolite of PA after hydrolysis, has been detected in the urine of men exposed to PA $^{44}$ but it is not clear if systemic absorption occurs from the respiratory or gastrointestinal tracts. A 1964 review commented on the lack of systemic toxicity in animal studies ${ }^{53}$ but systemic symptoms in man have been reported frequently, particularly influenza like symptoms of fever, malaise, and headache, often accompanied by respiratory symptoms (table 1). Some authors have attributed such symptoms to acid anhydrides, others to exposures different from, but occurring in parallel with, acid anhydrides, such as vanadium pentoxide, benzene, or naphthalene in PA production, ${ }^{5}$ or solvents in phthalate production. ${ }^{16}$

\section{Hypersensitivity}

The reactive anhydride group so useful for extending and cross linking polymeric chains also reacts readily with amino acids. Protein chemists use acid anhydrides as laboratory reagents because of their property of linking with lysine. ${ }^{8586}$ This explains their effectiveness as haptens and as causes of occupational hypersensitivity. The major form is allergic asthma, with or without rhinitis, conjunctivitis, or urticaria, called type I hypersensitivity in the 1963 classification of Gell and Coombs (table 1) ${ }^{87}$ It has been suggested that acid anhydrides cause haemoptysis through a type II response and systemic influenza like symptoms through a type III response ${ }^{88}$; these are discussed below. The evidence for contact dermatitis (Gell and Coombs type IV) is slight. PA was included in a review of agents known to cause both asthma and contact dermatitis, but no supporting references were quoted. ${ }^{89}$ Contact dermatitis has been reported to materials containing MA but could equally have been caused by other chemicals. ${ }^{51}{ }^{52}$ The present reviewer has found one report of a positive patch test to PA. ${ }^{53}$

\section{ASTHMA}

Of the 29 reports traced by the author which refer to asthma caused by acid anhydrides, most are of PA induced asthma. ${ }^{3471725-33353942-4446}$ Asthma caused by TMA, ${ }^{22} 3138394147$ TCPA, ${ }^{344048}$ and MA $^{3647}$ appears less common and there are single case reports only of asthma caused by PMDA, ${ }^{37} \mathrm{HA}^{43}$ and HHPA. ${ }^{45}$ Twenty five of the 29 have included either a challenge test or an immunological test (table 3). Surprisingly few publications (only nine) have included results from both types of test, of which only six 323440444648 used challenge tests which would be technically acceptable today. Of the four using neither type of test, three were early reports ${ }^{347}$ and one was a review of Swiss social security benefit claims. ${ }^{27}$ There have also been some unreferenced statements that PA and MA cause asthma. ${ }^{89-91}$

CHALLENGE TESTS

Sixteen reports included challenge tests. The first formal inhalation challenge test was reported from

Table 3 Reports of asthma caused by acid anhydrides

\begin{tabular}{lllll}
\hline $\begin{array}{l}\text { Laboratory } \\
\text { or workplace } \\
\text { challenge test }\end{array}$ & \multicolumn{2}{l}{ Immunological reactivity } & \\
\cline { 2 - 5 } & Positive & Negative & No test & Total \\
\hline Positive & $6^{223040444648}$ & $2^{3234}$ & $7^{313335374247}$ & 15 \\
Negative & 0 & $1^{28}$ & 0 & 1 \\
No test & $7^{25293839414345}$ & $2^{1726}$ & $4^{34727}$ & 13 \\
Total & 13 & 5 & 11 & 29 \\
\hline
\end{tabular}


Table 4 Challenge tests in acid anhydride induced asthma

\begin{tabular}{|c|c|c|c|c|c|c|}
\hline \multirow{2}{*}{\multicolumn{2}{|c|}{$\begin{array}{l}\text { Report and } \\
\text { chemical }\end{array}$}} & & \multirow[b]{2}{*}{ No } & \multicolumn{2}{|c|}{ Response to test } & \multirow[b]{2}{*}{ Comments } \\
\hline & & & & Immediate & Late & \\
\hline $1977^{31}$ & UK & $\begin{array}{l}\text { PA } \\
\text { TMA }\end{array}$ & $\begin{array}{l}3 \\
1\end{array}$ & $\begin{array}{l}+ \\
+\end{array}$ & $\begin{array}{l}+ \\
+\end{array}$ & $\begin{array}{l}\text { Vapour ( } 2 \text { ), } 1 \text { breath, } 2 \text { mins. Dust (1) } 29 \% \text { for } 10 \text { mins } \\
\text { Vapour } 1 \text { breath }\end{array}$ \\
\hline $1977^{32}$ & USA & & 1 & + & + & Vapour 1.25 mins \\
\hline $\begin{array}{l}1978^{33} \\
1978^{34}\end{array}$ & $\begin{array}{l}\text { Japan } \\
\text { USA }\end{array}$ & $\begin{array}{l}\text { PA } \\
\text { TCPA }\end{array}$ & $\begin{array}{l}1 \\
3\end{array}$ & $\begin{array}{l}+ \\
-\end{array}$ & $\begin{array}{l}+ \\
+\end{array}$ & Mixing powders 20 mins \\
\hline $1983^{40}$ & UK & TCPA & 4 & $+(2 / 4)$ & + & $\begin{array}{l}\text { Dust } 30 \text { mins. Responses at } 1 \cdot 1-10 \% \text { in dust, } 67-630 \mu \mathrm{g} / \mathrm{m}^{3} \\
\text { in air (mean values), highest single reading } 961 \mu \mathrm{g} / \mathrm{m}^{3}\end{array}$ \\
\hline $1983^{42}$ & UK & PA & 1 & + & + & Vapour 5 breaths \\
\hline $1986^{46}$ & Sweden & PA & 2 & + & + & $\begin{array}{l}\text { Dust aerosol via mask. } 0.5 \mathrm{mg} / \mathrm{m}^{3} \text { for } 10 \mathrm{mins}, 6 \mathrm{mg} / \mathrm{m}^{3} \text { for } 5 \\
\text { mins }\end{array}$ \\
\hline $1987^{47}$ & UK & MA & 2 & + & + & Dust $1 \%$ for 5 mins $\dagger$ \\
\hline & & TMA & 1 & + & - & Dust $1 \%$ for 5 mins \\
\hline $1987^{48}$ & UK & TCPA & 1 & + & + & Dust $1 \%$ for 30 mins \\
\hline
\end{tabular}

* Concentration (\%) of acid anhydride by weight in lactose powder.

+One case also had an isolated late response at $0.2 \%$ in dust and the response peak was several hours later than at $1 \%$ (fig 2 ). This study also showed an increase in non-specific bronchial responsiveness after late, but not immediate, asthmatic responses.

Romania in $1969^{28}$ and was negative. Interestingly, it was carried out with an alcoholic solution of PA. The first positive challenge test was reported in $1976^{30}$ and used a PA dust test, but an alcoholic solution of PA had also been tried before the dust test and elicited only a small response. The reason for the lack of response to alcoholic solutions may be simply that the dose was inadequate but animal studies have shown that large antigen particles of $100 \mu \mathrm{m}$ diameter elicit greater airway responses in sensitised guinea pigs than particles of 3 to $5 \mu \mathrm{m}$ diameter, or than antigen in solution, ${ }^{92}$ so possibly particle size was too small in the alcoholic solutions.

Nine of the 15 reports of positive challenge tests describe standardised, laboratory tests, with lung function monitoring for an adequate period (table 4). Several hours of observation are necessary to detect late asthmatic responses, which are a characteristic feature of occupational asthma in general, ${ }^{93}$ and of asthma caused by acid anhydrides, as table 4 shows. Twelve of the 20 patients in table 4 were tested at the Brompton Hospital..$^{3140478}$ Of the 20, 19 had either late asthmatic responses, maximal several hours after exposure, or dual responses with an immediate component within the first hour as well as a late response (fig 2). Only one had an isolated immediate response. ${ }^{47}$ These responses were provoked by low exposures-for example, PA and TMA vapour exposure for the duration of only one breath. ${ }^{31}$ In four patients tests were carried out over a range of exposure, which was monitored by environmental measurements ${ }^{40}$ and the size of the asthmatic response appeared to be dose related ${ }^{48}$ In the only study to monitor non-specific bronchial responsiveness, late asthmatic responses were accompanied by an increase in responsiveness but the one patient with an isolated immediate response had no change in responsiveness. ${ }^{47}$ Others have shown that the increased non-specific responsiveness after late asthmatic reactions may persist for days, or even weeks. ${ }^{9394}$ The importance of these observations is that they show that the late, not the immediate, asthmatic reaction is the reaction component associated with non-specific bronchial hyperresponsiveness, the characteristic pathophysiological feature of asthma, which is related quantitatively to the clinical severity of asthma. ${ }^{95}$

Of the remaining six reports of positive challenge tests, one is an abstract with information only on immediate responses ${ }^{44}$ and the other five monitored lung function for only a short period, three in the laboratory ${ }^{3035} 36$ and two in the workplace. ${ }^{22} 37$ It is difficult to interpret falls in lung function of short duration, because an asthmatic subject with hyperresponsive airways will experience transient airway narrowing to a range of inhaled irritants and may have a false positive response to acid anhydride. One "positive" challenge included in table 3 may well be such a response. ${ }^{35}$ A patient with meat wrapper's asthma had an immediate response within minutes to heated packaging labels and also to PA, which may be eluted from labels. The patient, however, was hyperresponsive to inhaled acetylcholine so may have responded to PA as an irritant. Late asthmatic responses were seen to heated PVC film and to epoxidised soya bean oil but no serological or skin tests to confirm PA hypersensivity were carried out so it is not clear if PA causes meat-wrapper's asthma as was claimed.

\section{IMMUNOLOGICAL TESTS}

Many low molecular weight chemicals other than acid anhydrides cause asthma, such as isocyanates, amines, plicatic acid (in western red cedar wood) and abietic acid (believed to be the agent in colophony responsible for asthma) but progress in developing reliable assays 

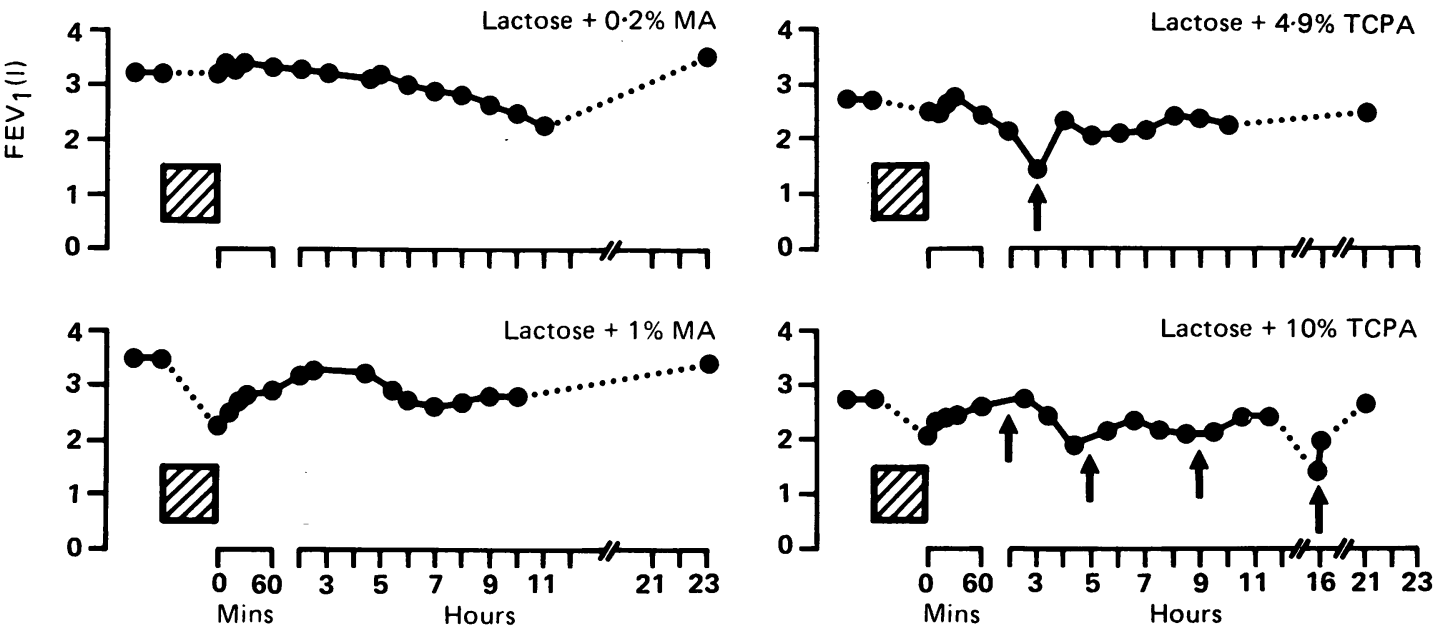

隹

Challenge test

Bronchodilator aerosol

Fig 2 Asthmatic responses in challenge tests. Patients with asthma caused by MA (left) and TCPA (right). Dust challenge tests were carried out with appropriate acid anhydride diluted in lactose powder. Dual asthmatic response was seen at a higher exposure than that provoking a late response. (Redrawn with permission, from J Allergy Clin Immunol. ${ }^{4047}$ )

for the immunological response to these chemicals has been slow. Such tests are useful in research and, particularly in patients exposed to several different chemicals, help to establish the cause of symptoms in clinical practice. The first report of asthma caused by an acid anhydride was by Kern in $1939^{25}$ and was of an industrial chemist with asthma and rhinitis caused by PA. This was also the first report to describe an immunological response to acid anhydride: the patient had weals to scratch tests with PA crystals and serum reagin to PA, shown by a Prausnitz-Küstner test. Thirty years later, reagin was identified as a new antibody class and named IgE. This case report led to experiments in the 1940s in which a range of acid anhydrides was used to sensitise animals which developed weals in scratch tests, occasionally generalised urticaria, and had a serum antibody resembling human reagin. ${ }^{66-69}$ The first description of a specific response in an in vitro assay was of lymphocyte transformation in $1972 .{ }^{29}$ Serum IgE antibodies to acid anhydride were shown first in $1976^{30}$ and IgG antibodies in $1977 . .^{22}$ IgA and IgM antibodies ${ }^{96}$ and histamine release from leucocytes ${ }^{22}$ have been reported.

Table 5 summarises the results of studies which have measured serum antibody to acid anhydrides in cases of acid anhydride induced asthma. Most cases have serological reactivity to acid anhydride, both IgE and IgG, but IgE appears to discriminate cases of asthma from exposed workers without asthma better than $\mathrm{IgG}$, because the prevalence of IgG is high in exposed workers. Although most of the cases and controls in table 5 were selected subjects, investigations on a complete series of cases from one factory and on the population from which they were drawn have confirmed the relative frequency of $\mathrm{IgE}$ and IgG antibody. All of a group of seven cases of TCPA asthma ${ }^{40}$ had IgE antibody to TCPA, compared with $8 \%$ of 300 
Table 5 Serum IgE and IgG antibody in acid anhydride induced asthma

\begin{tabular}{|c|c|c|c|c|c|c|c|c|}
\hline & & & \multicolumn{3}{|c|}{ Cases of asthma } & \multicolumn{3}{|c|}{ Exposed but no asthma } \\
\hline \multicolumn{3}{|c|}{ Report and chemical } & No & $\operatorname{Ig} E(\%)$ & $\operatorname{Ig} G(\%)$ & No & $\operatorname{Ig} E(\%)$ & $\operatorname{Ig} G(\%)$ \\
\hline $\begin{array}{l}1977^{22} \\
1981^{38} \\
1982^{39 *} \\
1983^{40 \dagger} \dagger \\
1984^{44} \\
1985^{45}\end{array}$ & $\begin{array}{l}\text { USA } \\
\text { USA } \\
\text { USA } \\
\text { UK } \\
\text { Finland } \\
\text { USA }\end{array}$ & $\begin{array}{l}\text { TMA } \\
\text { TMA } \\
\text { PA, TMA } \\
\text { TCPA } \\
\text { PA } \\
\text { HHPA }\end{array}$ & $\begin{array}{l}4 \\
1 \\
5 \\
7 \\
3 \\
4\end{array}$ & $\begin{array}{r}75 \\
100 \\
40 \\
100 \\
100 \\
100\end{array}$ & $\begin{array}{c}100 \\
100 \\
60 \\
100 \\
? \\
50\end{array}$ & $\begin{array}{l}10 \\
19 \\
15 \\
300,14 \\
64 \\
23\end{array}$ & $\begin{array}{r}? \\
11 \\
13 \\
8 \\
? \\
35\end{array}$ & $\begin{array}{r}100 \\
63 \\
20 \\
29 \\
56 \\
39\end{array}$ \\
\hline
\end{tabular}

? Number of significant antibody level not reported.

* Including two cases of rhinitis.

† IgE results in 300 exposed workers taken from a survey at the factory where the seven cases had worked. ${ }^{97}$ IgG results taken from a study which included the seven cases and 14 exposure matched controls without serum IgE from the factory survey. ${ }^{48}$

exposed workers without TCPA asthma. ${ }^{97}$ By contrast, all cases had IgG as did $29 \%$ of a sample of exposed workers. ${ }^{48}$ As workers with IgE were excluded from this sample, the true prevalence of IgG in the factory was probably higher than $29 \%$. It is possible that the formation of IgG antibody is a reflection of exposure to acid anhydride, but the formation of IgE reflects clinical hypersensitivity.

It is often proposed that low molecular weight chemicals cause asthma by several pathways, including non-immunological mechanisms. A recent survey of 118 Swedish workers exposed to PA found that symptoms in $21(18 \%)$ met a questionnaire based definition of occupational asthma. ${ }^{46}$ The authors suggested that some of these cases had asthma caused by a non-immunological mechanism as, in three, symptoms improved despite continued exposure and only $27 \%$ of those with occupational asthma who were tested $(3 / 11)$ had a positive scratch test to pulverised PA crystals. The authors further suggested that temporary heavy exposure might have been the cause of asthma in the three cases whose asthma improved. ${ }^{46}$ Heavy exposure to mucosal irritants is known to cause bronchial hyperresponsiveness which may persist for months or years. ${ }^{93}$ This has been termed "reactive airways dysfunction syndrome," but the distinction from asthma seems arbitrary. The negative skin tests, though, may be false negatives as they were carried out with PA crystals and may have been insensitive. Forty years ago, Chase commented that reactions to haptenprotein conjugates were stronger than those to the hapten alone in animals sensitised by low molecular weight chemicals. ${ }^{69}$ This has been confirmed recently by in vitro inhibition studies which show that serum antibodies in sensitised workers are directed against the combination of hapten with human protein, rather than the hapten alone. ${ }^{439899}$

Five papers have reported failure to confirm hypersensitivity by immunological tests (table 3 ). Insensitive techniques may explain these negative results: skin tests in one, ${ }^{17}$ two,${ }^{28}$ and four ${ }^{26}$ patients using PA rather than PA-protein conjugate and tests for precipitating antibodies in one $e^{34}$ and two ${ }^{28}$ patients, rather than the recent sensitive assays for IgG antibody. ${ }^{22}$ Other technical problems may also play a part. One study used a radioallergosorbent test for anti-PA IgE in a patient with PA asthma. ${ }^{32}$ It was negative but the authors commented that the serum had been stored for some time, perhaps not under optimal conditions. Another used the same test for anti-PA IgE in a patient with TCPA asthma, some years after removal from exposure. ${ }^{34}$ Although there is cross reactivity between TCPA and PA, the test results in TCPA asthma are lower with PA than TCPA ${ }^{99}$ and levels of anti-TCPA antibody fall after removal from exposure. ${ }^{100}$ The antibody activity may have been too low at the time of the test to be detected using PA. Nevertheless, even studies using technically satisfactory immunological tests find no evidence of hypersensitivity in occasional patients (table 5), so the possibility of alternative, nonimmunological mechanisms cannot be excluded.

\section{FACTORS CAUSING ASTHMA}

The exposures that provoke asthma in a sensitised patient may be no guide to those which cause sensitisation in the first place. Little is known about the acid anhydride exposure that causes asthma. TMA at 1.7 to $4.7 \mathrm{mg} / \mathrm{m}^{32241}$ and 0.007 to $2.1 \mathrm{mg} / \mathrm{m}^{3} 388384$ has caused asthma and PA at 0.3 to $15 \mathrm{mg} / \mathrm{m}^{3} .{ }^{46}$ Heavy intermittent exposure may be important in causing occupational asthma, including acid anhydride induced asthma. ${ }^{101}$ The patient described in the first report of PA asthma, however, was a chemist whose exposure was indirect, from the nearby factory floor, ${ }^{25}$ so it is possible that direct, heavy exposure is not essential. A recent case of asthma was caused by PA released from grinding freshly cured resin moulds, ${ }^{42}$ and this exposure may have been low.

Most cases of acid anhydride induced asthma appear to develop in the first few years of exposure. The median latent interval of PA asthma was less than one year in a Swedish survey ${ }^{46}$ and cases of TCPA asthma developed within two years of the introduction of TCPA to an epoxy coating process. ${ }^{4097100}$ Most 
studies of occupational asthma show similar short latent intervals.

Atopy is usually defined on skin reactivity in prick tests with common allergens, such as pollens and house dust mites, sometimes also on a personal or family history of allergic disease. It is recognised as a risk factor for occupational asthma caused by some agents, notably those of biological origin..$^{93101}$ As with other low molecular weight chemicals, no study of asthma caused by acid anhydrides has noted a strong association with atopy. In a survey of TCPA workers in which 276 exposed workers had skin prick tests and gave a blood sample $12 \%$ of atopic subjects had serum IgE antibody to TCPA compared with $6 \%$ of nonatopic subjects, a relative risk of two, though not statistically significant, ${ }^{97}$ and this order of risk has been observed for atopy and PA asthma ${ }^{46}$ in Sweden.

In the survey of TCPA workers there was a significant, sixfold excess of anti-TCPA IgE in current smokers, so smoking was more important than atopy. ${ }^{97}$ All the cases of TCPA asthma from this factory were current smokers. ${ }^{40}$ In an earlier series of cases of TCPA asthma three of the five were current smokers and two ex-smokers. ${ }^{34}$ A single case of PA asthma described by Maccia and colleagues was a smoker, ${ }^{30}$ as were the three of the four cases whose smoking habits were reported by Fawcett et al. ${ }^{31}$

Smoking has been increasingly noted to be a risk factor for occupational allergy in recent years. Smokers are more likely than non-smokers to have serum IgE (or skin prick test reactivity) to enzyme detergents, ispaghula, and raw coffee dust ${ }^{93101} 102$ and tobacco smoke has an adjuvant effect for sensitisation with ovalbumin in experimental animals. ${ }^{103}$ Occupational asthma is more common in smoking enzyme detergent workers and snow crab processors ${ }^{101102}$ but this association was not observed in PA asthma in Sweden $^{46}$ or in western red cedar asthma. ${ }^{93}$ One explanation for different patterns of association with atopy or smoking in different studies may be the selection of subjects. Botham and colleagues, ${ }^{104}$ in a longitudinal study of laboratory workers newly exposed to animals, noted that atopic subjects were at increased risk of occupational allergy, including asthma, in the first year of employment but that the association disappeared in the second and third years when the incidence fell in atopic subjects and rose in non-atopic subjects. ${ }^{104}$ The same time "window" of risk may operate for smoking as well as for atopy.

Smoking has a different effect on the induction of IgG antibody and it is non-smokers who are at greatest risk. ${ }^{102}$ The explanation for these contrasting effects is not known, though it presumably lies in the complex immunodepressant effects of smoking, perhaps also in its capacity to increase mucosal permeability to small molecules. ${ }^{102}$ No study has yet reported any increase in antiacid anhydride IgG production by non-smokers, though it seems possible that this occurs.

\section{PROGNOSIS}

Seven patients with TCPA asthma improved considerably after leaving the firm where they were exposed to TCPA but still had respiratory symptoms and required bronchodilator therapy more than four years later; five tested by inhalation of histamine had bronchial hyperresponsiveness in the range seen in mild asthma. ${ }^{100}$ As none had asthma before exposure to TCPA the symptoms and functional disorder were probably a consequence of developing occupational asthma. Follow up studies of asthma caused by other occupational agents have shown a similar persistence of mild to moderate asthma. ${ }^{93}$ No other formal studies of acid anhydride asthma after cessation of exposure have been published, though several case reports mention improvement after leaving exposure.

In addition to persistent asthma, these cases of TCPA asthma also showed persistent immunological reactivity (fig 3). ${ }^{100}$ Weal responses to TCPA conjugate were still elicited over four years after leaving occupational exposure and serum IgE antibody to TCPA declined slowly, with a half life of one year,

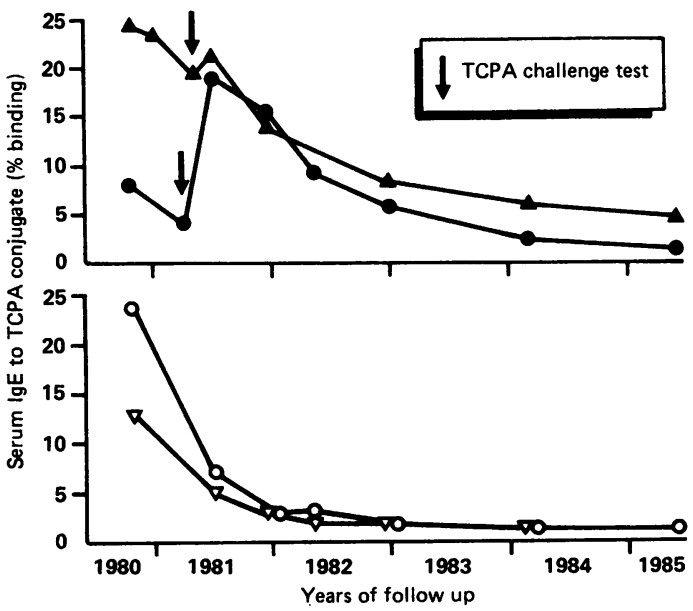

Fig 3 Serum IgE to a TCPA conjugate after leaving TCPA exposure. Patients with asthma caused by TCPA. Two indicated by open symbols (bottom) had no TCPA exposure during follow up and showed a steady fall in serum $\mathrm{IgE}$ antibody to TCPA conjugate. Two indicated by closed symbols (top) had challenge tests with TCPA in $1981^{40}$ and IgE rose afterwards, then fell. IgE fell to low levels but value were still above range in unexposed workers from same factory at which patients had worked when they developed occupational asthma. ${ }^{97}$ (Redrawn, with permission, from $J$ Allergy Clin Immunol. ${ }^{100}$ ) 
suggesting continued production of antibody or release of preformed antibody from cellular reservoirs. In four of the seven cases who had inhalation challenge tests a rise in $\mathrm{IgE}$ antibody occurred after the tests even though the exposure to TCPA was small: three to five half hour exposures to low environmental concentrations $\mathrm{s}^{40}$ (and table 4). The practical implication of these findings is that, in sensitised patients who remain at work with environmental or other controls monitoring serum antibody may help to monitor exposure and distinguish exacerbations of symptoms caused by exposure to acid anhydride from exacerbations with some other cause-for example, respiratory tract infection. Monitoring is already carried out in some workplaces which handle TMA, and reductions in anti-TMA antibody levels have been observed in workers after a reduction in exposure to TMA..$^{48384}$

\section{OTHER ILLNESSES POSSIBLY CAUSED BY HYPERSENSITIVITY}

Papers about hypersensitivity to acid anhydrides have dominated publications in recent years. In part, this seems due to a fall in interest in direct toxicity because reductions in occupational exposure have reduced the severity of mucosal and skin irritation. The increase in the number of reports of hypersensitivity may have a more complex explanation, however. Firstly, allergic asthma was probably underdiagnosed in the postwar years. There was considerable "background noise" from respiratory irritation, with which the symptoms of asthma are easily confused. The detection of occupational asthma starts from a recognition that respiratory symptoms are due to asthma and are temporally related to work. An outbreak of TCPA asthma was detected when a firm sought advice on controlling respiratory sickness absence and an employment medical adviser found that seven workers who had required sick leave had symptoms of work related asthma. ${ }^{4097100} \mathrm{~A}$ series of investigations on American TMA workers started when a company doctor decided that the known irritant effects of acid anhydrides did not adequately explain symptoms at his plant, changed his "level of suspicion as to the mode of action of TMA" and asked for a specialist opinion. ${ }^{105}$ Standardised challenge tests for investigating occupational asthma were developed only in the 1960 s and 1970s. ${ }^{106}$

Secondly, the increase has paralleled improvements in immunological diagnostic technology and possibly there is now some overdiagnosis of hypersensitivity to acid anhydrides, diagnosis being based on the finding of an antibody, rather than on clinical criteria. Pepys has commented that, without evidence of a causal association between an antibody and a clinical disorder, the presence of an antibody is evidence only of exposure. ${ }^{107}$ Two clinical disorders recognised for many decades (table 1) have been attributed in recent years to hypersensitivity ${ }^{88}$ : an influenza like illness and pulmonary haemorrhage. Attribution of an immunological mechanism followed detection of IgG antibodies.

\section{INFLUENZA LIKE SYMPTOMS}

Influenza like symptoms caused by PA were first noted by Donnat ${ }^{7}$ and then by other European authors, before in vitro assays for antibodies to PA were available (table 1). They were noted again in the United States in TMA workers in 1977. ${ }^{22}$ The workers named the illness "TMA flu" and it was later termed the "late respiratory systemic syndrome" (LRSS). It is characterised by respiratory symptoms late in, or after, the workshift, with aching, shivering, fever, and malaise, resembling the symptoms of extrinsic allergic alveolitis. ${ }^{88}$ As table 4 shows, however, late onset respiratory reactions are characteristic of acid anhydride asthma and no challenge tests have been carried out to determine if TMA flu is simply a late asthmatic response nor have there been lung biopsies or bronchoalveolar lavage studies to confirm a parenchymal immunological response distinct from asthma. Febrile symptoms have been described in acid anhydride induced asthma ${ }^{7174}$ and also in asthma caused by solder fumes ${ }^{108}$ Alternatively, the symptoms may not be immunologically mediated. They tend to occur in workshifts with high exposure to TMA $^{22}$ and the descriptions resemble those of other occupational febrile syndromes, such as metal fume fever or polymer fume fever, which are not thought to have an immunological basis.

One group of investigators, working in Chicago, has compared influenza like symptoms with the presence of IgG antibody to TMA and has concluded that the symptoms are IgG mediated ${ }^{88}$ Some of their studies are difficult to interpret, as symptoms were classified with a knowledge of the immunological status, at least of skin reactivity to TMA. ${ }^{224198}$ Two studies have categorised symptoms independently of immunological tests. ${ }^{38}{ }^{39}$ Both included 20 workers: in one, 4/4 with influenza had IgG compared with $9 / 16(56 \%)$ without $\mathrm{flu}^{38}$; in the second the respective proportions were $1 / 2$ and $5 / 18(28 \%){ }^{39}$ The association of influenza like symptoms with IgG antibody is thus weaker than that of asthmatic symptoms with IgE antibody because of the high prevalence of $\mathrm{IgG}$ in exposed workers without symptoms.

If TMA flu is a form of hypersensitivity, rather than direct toxicity from high TMA exposure (which would also tend to induce IgG antibody), then it does not appear to be extrinsic allergic alveolitis, as the term is generally understood. Clinical examinations and chest radiographs were normal ${ }^{22}$ and some workers have continued working with lower levels of TMA with 
some improvement in symptoms. ${ }^{418384}$ In classic extrinsic allergic alveolitis, such as farmer's lung, there are crackles and pulmonary shadowing in acute episodes and pulmonary fibrosis may occur if exposure continues, even low exposure. Until.patients with influenza like symptoms have been investigated in more detail, the case for hypersensitivity must be regarded as unproved. The association of influenza with IgG antibody could well be coincidental rather than causal, a consequence of high TMA exposure causing both antibody and symptoms.

\section{PULMONARY HAEMORRHAGE}

The history of aetiological hypotheses about pulmonary haemorrhage in workers exposed to acid anhydrides is similar to that of influenza like symptoms. The authors of early reports, before in vitro immunological tests were available (table 1), suggested that it was a form of acute chemical pulmonary oedema and haemorrhage, which may occur after the inhalation of several chemicals. Recent cases in TMA workers in the United States have been found to have anti-TMA IgG antibody, and hypersensitivity has been proposed as at least part of the mechanism for the illness. Because of the severity of the illness, these 12 patients have been investigated in much more detail than patients $v$. .th TMA flu. ${ }^{23245455}$ Lung biopsies were carried out in four and showed non-specific changes consistent with acute lung injury. ${ }^{2324} 54$ Immunofluorescent studies were negative, suggesting antibodies were not involved in the tissue injury. Several patients also had evidence of haemolysis, but direct and indirect antiglobulin (Coombs) tests were negative. ${ }^{2454}$ Without objective confirmation that antibodies to TMA participated in the lung and red cell damage, however, their presence must be regarded as evidence of TMA exposure only. One of these workplaces had fairly low TMA levels of 0.1 to 0.27 $\mathrm{mg} / \mathrm{m}^{3}{ }^{24}$ (not $\mathrm{mg} / \mathrm{mm}^{3}$ as printed) (F A Herbert, personal communication). The workers, however, sprayed powder epoxy resin on to heated pipes with little or no respiratory protection in a small workshop with poor ventilation. This suggests high exposure and the environmental survey was made after cases presented and possibly after improvements in hygiene. The descriptions of working practices in the three other small workplaces are similar. It is important that those using acid anhydrides in these circumstances are aware of the risk of severe, potentially life threatening pulmonary haemorrhage. One of these 12 cases required mechanical ventilation and transfusion of 14 units of blood. ${ }^{54}$

\section{Summary}

The studies to date have shown that acid anhydrides are mucosal and skin irritants and are also antigenic, stimulating a polyclonal antibody response in several immunoglobulin classes. There are many unanswered questions and suggestions that need confirmation. Although asthma is now well recognised and included in the first United Kingdom legislation on statutory benefit for occupational asthma, ${ }^{109}$ few publications have compared careful challenge studies with the results of immunological tests and there is only one description of its prognosis after the avoidance of exposure. ${ }^{100}$ Although most cases of asthma appear to be due to hypersensitivity, the possibility of other mechanisms remains. The aetiology of influenza like symptoms and of pulmonary haemorrhage is unclear. Hypersensitivity cannot be ruled out as a contributory factor, at least in part, but these conditions may of equally be the consequences of heavy exposure alone. i The least studied area is the long term consequences of repeated airway irritation.

There have been few population surveys, all cross sectional. Some were small ${ }^{1745}$ and others had a narrow frame of reference, such as a survey of eye symptoms in printers, ${ }^{13}$ or another evaluating symptoms and lung function in PA workers after exposure controls. ${ }^{110}$ The cross sectional design has limitations: healthy worker selection was shown in a Swedish study $^{46}$ and, in an extreme form, in a survey of TCPA workers, where no cases of TCPA induced asthma remained after a group of cases had left. ${ }^{97}$ Except for some studies following the effects of exposure controls, ${ }^{418384}$ no longitudinal studies have been performed. Environmental exposure may be measured using high performance liquid chromatography ${ }^{111}$ or gas chromatography. ${ }^{112}$ Exposure data are provided in some reports but none has correlated individual exposure with response variables. Smoking and, to a lesser extent, atopy appear to be risk factors for asthma and for IgE antibody production but this has not been noted consistently, perhaps because of different selection factors in different populations. Exposure response relations and the role of individual susceptibility can be studied adequately only in careful longitudinal epidemiological studies.

This review was carried out for a thesis for the University of London MD. I thank Dr Anthony Newman Taylor and Dr Michael Topping for their $\mathrm{N}$ helpful comments on the manuscript and for their $N$ collaboration over several years on studies of the adverse effects of acid anhydrides.

\section{References}

1 Chief Inspector of Factories and Workshops. Annual report for 1937 London: HMSO, 1938:62.

2 Roche J. Les accidents causés par l'anhydride phtalique dans l'industrie. Paris Faculty of Medicine, 1947. (MD thesis.) 
3 Baader EW. Erkrankungen durch Phthalsäure und ihre Verbindungen. Archiv für Gewerbepathologie und Gewerbehygiene 1955;13:419-53. (English summary by Middleton EL. Bulletin of Hygiene 1955;30:699-700.)

4 Menschick H. Gesundheitliche Gefahren bei der Herstellung von Phthalsäureanhydrid. Archiv für Gewerbepathologie und Gewerbehygiene 1955;13:454-75. (English summary by Middleton EL. Bulletin of Hygiene 1955;30:698-9.)

5 Merleverde E, Elskens J. Les intoxications dues à l'anhydride phtalique. l'anhydride maléique et aux phtalates. Archives Belges de Médecine Sociale, Hygiène, Médecine du Travail et Médecine Lègale 1957;15:445-57.

6 Capellini A, Sartorelli E. Episodio di intossicazione collettiva da anidride acetica ed acido acetico. Med Lav 1967;58:108-12.

7 Donnat L. Syndrome d'irritation des voies aériennes supérieures et bronchiques par l'anhydride phtalique: syndrome asthmatiforme allergique. Médicine du Travail 1944;16:109-14.

8 Bernard E, Marchand M. Intoxication par l'anhydride phtalique. Archives de l'Institut de Médecine Légale et de Médicine Sociale de Lille 1945:1:39-44.

9 McLaughlin RS. Chemical burns of the human cornea. Am J Ophthalmo 1946;29:1355-62.

10 Chief Inspector of Factories. Annual report for 1945. London: HMSO, 1946:76.

11 Policard A, Gauthier G, Hugonnier R, Roche L. L'intoxication par l'anhydride phtalique. Archives des Maladies Professionelles de Medicine du Travail et de Securité Sociale 1949;10:70-2.

12 Bourret J, Gauthier G, Roche L. Intoxication par l'anhydride phtalique. Acta Med Leg Soc (Liege) 1950;3:33-7.

13 Tanaka S. Lesion of the eye caused by maleic anhydride vapour. Journal of Science of Labour 1956;32:117-26.

14 Kapustkina TW, Mendlin MS, Nikitenko AAN, Sannikova LK, Chimeczenko BF. Occupational health and hygiene of workers handling phthalic anhydride. Gig Tr Prof Zabol 1959;3:28-31.

15 Munari M, Tinazzi V. Aspetti della patologia da anidride ftalica. Rassegna di Medicina Industriale e di Igiene del Lavoro 1960;29:107-14.

16 Pisani F. Patologia degli operai addetti alla preparazione degli ftalati di ottile e di butile. Med Lav 1960;51:137-43.

17 Oltramare M. Troubles digestifs et respiratoires lors de l'utilisation des résines epoxyliques (Araldite). Revue Lyonnaise de Médecine 1961:10:1187-92.

18 Frede G. Gesundheitliche Gefahren bei der Herstellung von Phthalsäureanhydrid. Z Gesamte Hyg 1962;8:177-96. (English summary by Delafield ME. Bulletin of Hygiene 1962:37:810. English summary by Malten and Zielhuis. $^{\text {s8 }}$ )

19 Montejano B, Brazzanovich JA, Gómez OA. Problemas higienicoocupacionales en la fabricacion del anhidrido ftalico. Rev Asoc Méd Argent 1963;77:559-63.

20 Ghezzi I, Scotti P. Contributo clinico alla conoscenza della patologia da anidride ftalica e maleica. Med Lav 1965;56:746-52.

21 Petit J-M, Troquet $\mathbf{J}$, Melon J. Influence des émanations provenant des manipulations de résines éthoxylines sur les voies respiratoires. Archives des Maladies Professionnelles de Médicine du Travail et de Sécurite Sociale 1961;22:718-25.

22 Zeiss CR, Patterson R, Pruzansky JJ, Miller MM, Rosenberg M, Levitz D. Trimellitic anhydride-induced airway syndromes: clinical and immunologic studies. J Allergy Clin Immunol 1977;60:96-103.

23 Rice DL, Jenkins DE, Gray JM, Greenberg SD. Chemical pneumonitis secondary to inhalation of epoxy pipe coating. Arch Environ Health 1977;32:173-8

24 Herbert FA, Orford R. Pulmonary hemorrhage and edema due to inhalation of resins containing trimellitic anhydride. Chest 1979;76:546-51.

25 Kern RA. Asthma and allergic rhinitis due to sensitization to phthalic anhydride: report of a case. J Allergy 1939;10:164-5.

26 Gervais $P$. L'asthme professionnel dans l'industrie des matières plastiques. Poumon Coeur 1966;22:497-511.

27 Marti M-C. Lésions dues aux résines époxyliques en Suisse II. Praxis der Pneumologie 1968;36:1229-34.

28 Popa V, Teculescu D, Stanescu D, Gavrilescu N. Bronchial asthma and asthmatic bronchitis determined by simple chemicals. Diseases of the Chest 1969;56:395-404

29 Gervais P. Efthymiou ML, Hebert S. Diamant-Berger O. Diagnostic et physiopathologie de l'asthme dû à l'anhydride phthalique: intérêt du test de transformation lymphoblastique. Eur J Toxicol 1972;5:106-9.

30 Maccia CA, Bernstein IL, Emmett EA, Brooks SM. In vitro demonstration of specific IgE in phthalic anhydride hypersensitivity. Am Rev Respir Dis 1976;113:701-4.

31 Fawcett IW, Newman Taylor AJ, Pepys J. Asthma due to inhaled chemical agents - epoxy resin systems containing phthalic acid anhydride, trimellitic acid anhydride and triethylene tetramine. Clin Allergy 1977;7: 1-14.

32 Chester EH, Schwartz HJ, Payne CB Jr, Greenstein S. Phthalic anhydride asthma. Clin Allergy 1977;7:15-20.
33 Ohta T, Hara I, Miyagi N. A case study on bronchial asthma due to phthalic anhydride. Japanese Journal of Industrial Health 1978;20:228-9.

34 Schlueter DP. Banaszak EF, Fink JN, Barboriak J. Occupational asthma due to tetrachlorophthalic anhydride. J Occup Med 1978;20:183-8.

35 Pauli G. Bessot JC, Kopferschmitt MC, et al. Meat wrapper's asthma: identification of the causal agent. Clin Allergy 1980;10:263-9.

36 Guérin JC, Deschamps O, Guillot YL, Chavaillon JM. Kalb JC. A propos d'un cas d'asthme à l'anhydride maléique. Poumon Coeur 1980;36:393-5.

37 Meadway J. Asthma and atopy in workers with an epoxy adhesive. $\mathrm{Br} J \mathrm{Dis}$ Chest 1980;74:149-54.

38 Sale SR, Roach DE, Zeiss CR, Patterson R. Clinical and immunologic correlations in trimellitic anhydride airway syndromes. $J$ Allergy Clin Immunol 1981;68:188-93

39 Bernstein DI, Patterson R, Zeiss CR. Clinical and immunologic evaluation of trimellitic anhydride- and phthalic anhydride-exposed workers using a questionnaire with comparative analysis of enzyme-linked immunosorbent and radioimmunoassay studies. $J$ Allergy Clin Immunol 1982;69: 311-8.

40 Howe W, Venables KM, Topping MD, et al. Tetrachlorophthalic anhydride asthma: evidence for specific IgE antibody. J Allergy Clin Immuno 1983;71:5-11.

41 Zeiss CR, Wolkonsky P, Chacon R, et al. Syndromes in workers exposed to trimellitic anhydride: a longitudinal clinical and immunologic study. Ann Intern Med 1983;98:8-12.

42 Ward MJ, Davies D. Asthma due to grinding epoxy resin cured with phthalic anhydride. Clin Allergy 1983;13:165-8.

43 Bernstein DI, Gallagher JS, D'Souza L, Bernstein IL. Heterogeneity of specific-IgE responses in workers sensitised to acid anhydride compounds. J Allergy Clin Immunol 1984;74:794-801.

44 Ahlberg RW, Keskinen H, Kuuliala D, Nordman H, Pfaffli P. Respiratory tract allergy caused by phthalic anhydride: degree of exposure and specific antibodies. Hygiea 1984;93:123-4. (HSE translation 86/135.)

45 Moller DR, Gallagher JS, Bernstein DI, Wilcox TG, Burroughs HE, Bernstein IL. Detection of IgE-mediated respiratory sensitization in workers exposed to hexahydrophthalic anhydride. J Allergy Clin Immunol 1985;75:663-72.

46 Wernfors M, Nielsen J, Schütz A, Skerfving S. Phthalic anhydride-induced occupational asthma. Int Arch Allergy Appl Immunol 1986;79:77-82.

47 Durham SR, Graneek BJ, Hawkins R, Newman Taylor AJ. The temporal relationship between increases in airway responsiveness to histamine and late asthmatic responses induced by occupational agents. $J$ Allergy $C l i n$ Immunol 1987;79:398-406.

48 Venables KM. Occupational asthma caused by tetrachlorophthalic anhydride. London: University of London, 1987. (MD thesis.)

49 Maeder E. Rhinitis vasomotorica auf Epoxydharz-Härter (Phthalsäureanhydrid). Dermatologica 1964;129:416-22.

50 Weil AJ, Rogers HE. Allergic reactivity to simple aliphatic acids in man. $J$ Invest Dermatol 1951;17:227-31.

51 Schwartz L. An outbreak of dermatitis from hair lacquer. Public Health Rep 1943;58:1623-5.

52 Klauder JV. Sensitization dermatitis from "Scottissue" towels. American Medical Association Archives of Dermatology and Syphilology 1948:57:415-6.

53 Malten KE, Zielhuis RL. Industrial toxicology and dermatology in the production and processing of plastics. Amsterdam: Elsevier, 1964.

54 Rivera M, Nicotra MB, Byron GE, et al. Trimellitic anhydride toxicity: a cause of acute multisystem failure. Arch Intern Med 1981;141:1071-4

55 Ahmad D, Morgan WKC, Patterson R, Williams T, Zeiss CR. Pulmonary haemorrhage and haemolytic anaemia due to trimellitic anhydride. Lancet 1979;ii:328-30.

56 Riboli E, Bai E, Berrino F, Merisi A. Mortality from lung cancer in an acetylene and phthalic anhydride plant. Scand J Work Environ Health 1983;9:455-62.

57 Stepanov MG. Arginine and glycocoll in acute phthalic anhydride poisonings. Farmakol Toksikol 1964;27:741-2.

58 Fielder RJ, Dale EA. Trimellitic anhydride (TMA). In: Toxicity review 8 London: HMSO, 1983.

59 Sale SR, Patterson R, Zeiss CR, Fiore M, Harris KE, Yawn D. Immune response of dogs and rabbits to intrabronchial trimellitic anhydride. In Arch Allergy Appl Immunol 1982:67:329-34.

60 Pludro G, Karlowski K, Mankowska M, Woggon H, Uhde WJ. Toxicological and chemical studies of some epoxy resins and hardeners I. Determination of acute and subacute toxicity of phthalic acid anhydride. 4,4-diaminodiphenylmethane and of the epoxy resin Epilox EG-24. Acto Pol Pharm 1969;26:353-8.

61 Monsanto. Material safety data sheet on tetrachlorophthalic anhydride. Brussels: Monsanto Europe SA, 1977.

62 Carpenter CP, Smyth HF Jr. Chemical burns of the rabbit cornea. Am Ophthalmol 1946;29:1363-72.

63 Winter CA. Tullius EJ. The irritating effects of maleic acid and of maleic 
anhydride upon the eyes of rabbits. Am J Ophthalmol 1950;33:387-8.

64 Hine CH, Kodama JK, Anderson HH, Simonson DW, Wellington JS. The toxicology of epoxy resins. AMA Archives of Industrial Health 1958;17:129-44.

65 Burbach JPE. The action of furan-maleic anhydride adduct and some of its derivatives. Dermatologica 1967;135:103-6.

66 Jacobs JL, Golden TS, Kelley JJ. Immediate reactions, to anhydrides, of wheal-and-erythema type. Proc Soc Exp Biol Med 1940;43:74-7.

67 Jacobs JL. Immediate generalized skin reactions in hypersensitive guinea pigs. Proc Soc Exp Biol Med 1940;43:641-3.

68 Landsteiner K, Chase MW. Experiments on transfer of cutaneous sensitivity to simple compounds. Proc Soc Exp Biol Med 1942;49:688-90.

69 Chase MW. Studies on the sensitization of animals with simple chemical compounds X. Antibodies inducing immediate-type skin reactions. $J$ Exp Med 1947;86:489-514.

70 Chase MW. Models for hypersensitivity studies. In: Lawrence HS, ed. Cellular and humoral aspects of the hypersensitive states. London: Cassell, 1959:251-78.

71 Patterson R, Roberts M, Harris KE, Levitz D, Zeiss CR. Pulmonary and systemic immune responses of rhesus monkeys to intrabronchial administration of trimellitic anhydride. Clin Immunol Immunopathol 1980;15: 357-66.

72 Liu F-T, Bargatze RF, Katz DH. Induction of immunologic tolerance to the trimellitate haptenic group in mice: model for a therapeutic approach to trimellitic anhydride-induced hypersensitivity syndromes in humans? $J$ Allergy Clin Immunol 1980;66:322-6.

73 Wei B-Y, Holford-Strevens V, Carter BG, Sehon AH. Suppression of the anti-trimellityl (TM) IgE response in mice by conjugates of TM with polyvinyl alcohol. Immunology 1984;51:687-96.

74 Chandler MJ, Zeiss CR, Leach CL, et al. Levels of antibody in bronchoalveolar lavage (BAL) and serum in an animal model of trimellitic anhydride-induced lung injury. $J$ Allergy Clin Immunol 1987;80:223-9.

75 Lee H, Neville K. Handbook of epoxy resins. New York: McGraw-Hill, 1967.

76 May CA, Tanaka Y. Epoxy resins. Chemistry and technology. New York: Marcel Dekker, 1973

77 Hamilton A, Hardy HL. Industrial toxicology. 3rd ed. USA: Publishing Sciences Group, 1974.

78 Key MM, Henschel AF, Butler J, Ligo RN, Tabershaw IR, Ede L, eds. Occupational diseases: a guide to their recognition. Washington: United States Government Printing Office, 1977

79 Turner GPA. Introduction to paint chemistry and principles of paint technology, 2nd ed. London: Chapman and Hall, 1980.

80 Heikkilä P, Hietanen M, Kakko K, Yrjänheikki E, Hassi J, Tolonen M. Occupational hygiene survey of 99 small workplaces with special reference to occupational health services. Scand J Work Environ Health 1979;5(suppl 2):30-40.

81 Fawcett RL. Air pollution potential of phthalic anhydride manufacture. T12 chemical committee informative report No 11.J Air Pollut Control Assoc 1970;20:461-5.

82 Grigorieva KV. On the atmospheric air pollution with maleic anhydride. Gig Sanit 1964;29:8-12.

83 Bernstein DI, Roach DE, McGrath KG, Larsen RS, Zeiss CR, Patterson R. The relationship of airborne trimellitic anhydride concentrations to trimellitic anhydride-induced symptoms and immune responses. $J$ Allergy Clin Immunol 1983:72:709-13.

84 McGrath KG, Roach D, Zeiss CR, Patterson R. Four-year evaluation of workers exposed to trimellitic anhydride: a brief report. $J$ Occup Med 1984;26:671-5.

85 Habeeb AFSA, Cassidy HG, Singer SJ. Molecular structural effects produced in proteins by reaction with succinic anhydride. Biochim Biophys Acta 1958;29:587-93.

86 Butler PJG, Harris JI, Hartley BS, Leberman R. The use of maleic anhydride for the reversible blocking of amino groups in polypeptide chains. Biochem $J$ 1969;112:679-89.

87 Gell PGH, Coombs RRA. The classification of allergic reactions underlying disease. In: Gell PGH, Coombs RRA, eds. Clinical aspects of immunology. Oxford: Blackwell, 1963:317-37.

88 Patterson R, Zeiss CR, Pruzansky JJ. Immunology and immunopathology of trimellitic anhydride pulmonary reactions. J Allergy Clin Immunol
1982;70:19-23.

$89 \mathrm{Key}$ MM. Some unusual allergic reactions in industry. Arch Dermatol 1961;83:57-60

90 Lefaux R. La toxicologie des matières plastiques en rapport avec l'hygiène industrielle. Archives des Maladies Professionnelles de Médicine du Travail et de Sécurité Sociale 1955;16:554-8.

91 Queries and minor notes (anonymous). Exposure to phthalic anhydride. JAMA 1957;163:1310-1

92 Wieslander E, Anderson P, Linden M, et al. Importance of particulate antigen for the induction of dual bronchial reaction in guinea-pigs. Agent Actions 1985;16:37-8.

93 Chan-Yeung M, Lam S. Occupational asthma. Am Rev Respir Dis 1986;133:686-703.

94 Cockcroft DW, Ruffin RE, Dolovich J, Hargreave FE. Allergen-induced increase in non-allergic bronchial reactivity. Clin Allergy 1977:7:503-13.

95 Cockcroft DW, Killian DN, Mellon JJA, Hargreave FE. Bronchial reactivity to inhaled histamine: a method and clinical survey. Clin Allergy 1977;7:235-43.

96 Patterson R, Zeiss CR, Roberts M, Pruzansky JJ, Wolkonsky P, Chacon R. Human antihapten antibodies in trimellitic anhydride inhalation reactions: immunoglobulin classes of anti-trimellitic anhydride antibodies and hapten inhibition studies. $J$ Clin Invest 1978;62:971-8.

97 Venables KM, Topping MD, Howe W, Luczynska CM, Hawkins R, Newman Taylor AJ. Interaction of smoking and atopy in producing specific IgE antibody against a hapten protein conjugate. $\mathrm{Br} \mathrm{Med} J$ 1985;290:201-4.

98 Zeiss CR, Levitz D, Chacon R, Wolkonsky P, Patterson R, Pruzansky JJ. Quantitation and new antigenic determinant specificity of antibodies induced by inhalation of trimellitic anhydride in man. Int Arch Allergy Appl Immunol 1980;61:380-8.

99 Topping MD, Venables KM, Luczynska CM, Howe W, Newman Taylor AJ. Specificity of the human IgE response to inhaled acid anhydrides. J Allergy Clin Immunol 1986;77:834-42.

100 Venables KM, Topping MD, Nunn AJ, Howe W, Newman Taylor AJ. Immunologic and functional consequences of chemical (tetrachlorophthalic anhydride)-induced asthma after four years of avoidance of exposure. J Allergy Clin Immunol 1987;80:212-8.

101 Venables KM. Epidemiology and the prevention of occupational asthma. $B$ J Ind Med 1987;44:73-5.

102 Lancet. Smoking, occupation, and allergic lung disease. Lancet 1985; ;:965

103 Zetterström O, Nordvall SL, Björkstén B, Ahlstedt S, Stelander M. Increased IgE antibody responses in rats exposed to tobacco smoke. $J$ Allergy $C l i n$ Immunol 1985;75:594-8.

104 Botham PA, Davies GE, Teasdale EL. Allergy to laboratory animals: a prospective study of its incidence and of the influence of atopy on its development. Br J Ind Med 1987;44:627-32.

105 Wolkonsky P. The industrial physician and occupational lung disease. Allergy Clin Immunol 1982;70:67-9.

106 Pepys J, Hutchcroft BJ. Bronchial provocation tests in etiologic diagnosis and analysis of asthma. Am Rev Respir Dis 1975;112:829-59.

107 Pepys J. Hypersensitivity diseases of the lungs due to fungi and organic dusts. Monographs in allergy 4. Basel: Karger, 1969.

108 Burge PS, Harries MG, O'Brien IM, Pepys J. Respiratory disease in workers exposed to solder flux fumes containing colophony (pine resin). Clin Allergy 1978;8:1-14.

109 Industrial Injuries Advisory Council Occupational asthma. London: HMSO, 1981. (Cmnd 8121.)

110 Ohta T. Ogawa T, Aoyama H, Hara I. A study on the health-status and working conditions of phthalic anhydride workers. Japanese Journal of Industrial Health 1979;21:61-7.

111 Purnell CJ, Bagon DA, Warwick CJ. The determination of organic contaminant concentrations in workplace atmospheres by high-performance liquid chromatography. In: Albaiges $J$, ed. Proceedings of II international congress on analytical techniques in environmental chemistry. Barcelona 1981. Oxford: Pergamon, 1981:203-19.

112 Rushing LG, Althaus JR, Thompson HC Jr. Simultaneous determination of trimellitic anhydride and its trimellitic acid impurity by GC/FID. $J$ Anal Toxicol 1982;6:290-3 